Andrews University

From the SelectedWorks of Gus Gregorutti

2012

THE MEXICAN IDEA OF TWOYEAR

UNIVERSITY DEGREES: A MODEL OF

OPPORTUNITIES AND CHALLENGES

Gus Gregorutti

Available at: https://works.bepress.com/gus_gregorutti/48/

bepress 


\title{
The Mexican idea of two-years university degree: A model of opportunities and challenges
}

\author{
Dr. Gustavo Gregorutti ${ }^{1}$
}

\section{Introduction}

At the beginning of the 80's, Mexico faced the reality of an economy that was mismatched, in many aspects, with its Northern neighbors. Revenues based on natural resources and maquiladoras, mainly in the north part of the country, were not enough to spin the wheel of progress for the whole nation. The world was changing and Mexico had to do something about it. Thus, the country rushed to a neoliberal agenda seeking to adjust to the international economy reducing federal investment as a central component of its growth and at the same time turning productivity to the global market with foreign capital investments that put Mexico's economy in consonance with international trade and OCDE countries (Didou, 2002).

These important and deep fluctuations impacted, among other sectors, public education. A set of new policies allowed private entrepreneurs to create universities as a way of expanding higher education. The government was trying to absorb the increasing demand of education with lesser public funding. The neoliberal strategy also promoted at least the following important changes on public higher education: a) Funding was linked to performance and not only to the needs that universities budgeted, a revolutionary change in the culture of state universities; b) a wave of assessing and controlling quality in traditional autonomous universities, that until then did not have any significant program of evaluation; c) the lack of linkage with the productive sector led to a reconsideration of efficiency and efficacy of public university with an emphasis on training more people in sciences and technology to bridge education with industry and businesses. The main idea was to align universities with the industrial sector that was, at the same time, competing to gain a place in a growing globalized economy. The university was pressed to become more relevant to the needs of this new paradigm of intertwined local and global flow of wealth (Ibarra Colado, 2002).

In addition to this overall context, and according to Ruiz Larraguivel (2007), there were also important social problems that influenced authorities from diverse government institutions to create an alternative training systems. Several communities in central states had serious economical underdevelopments with important community disparities. It is within this national and international background that the two-years university degree appeared at the beginning of the 90's, which was totally unheard in the Mexican academia.

Taking into account that this institution and its degrees has been a growing and positive contribution for low class and poor students, this paper focuses, first of all, on how employers see and value two-years degrees coming from the technological universities (TU). Second, based on interviews, it analyzes and challenges some of the Human Capital

\footnotetext{
${ }^{1}$ Dr. Gustavo Gregorutti works as an associate professor at the School of Education in the University of Montemorelos, Nuevo Leon, Northern Mexico. For further information he can be contacted at grego@um.edu.mx.
} 
Theory (HCT) assumptions. According to this theoretical framework, a trained person is the engine that moves an economy. It is assumed that students from lower classes with a degree, like the one obtained at technological universities, have a much better platform to finding a job. Does HCT explain effectively that two-years trained graduates can find jobs? The whole discussion in rooted in a theoretical dialogue to insert the phenomenon within a broader understanding. And finally, the discussion turns to the contributions and challenges this innovative model represents within the Mexican system of higher education. The discussion hinges around the model's strengths and weaknesses with policy alternatives to correct some of the problems exposed and examined throughout the paper.

Generally speaking, the chapter is aimed to depicting how this Technological University has been an experiment with incredible potential, but also, that there are important pitfalls that need urgent treatment. The issues presented and discussed in this paper can "spillover" to Latin America, since two-years degrees are rare in the whole region and may be a possible option for other countries.

\section{The Technological University}

Toward the end of 80's and beginning of 90's, the academic structures in Mexico were highly outdated and needed some important changes (Ornelas, 1995). Consequently, in 1991 the Secretary of Education ${ }^{2}$ in México launched a new system of higher education, namely the Technological University, an academic organization that has been a revolutionary step to offer a degree, called "University-trained Higher Technician" (Técnico Superior Universitario) and it is similar to what is obtained in a Community College at the end of two years. This associate degree, most of the times in a particular technological discipline, were set to train students to adjust to jobs' need and demand. In other words, these technicians are very much oriented to service and industrial sectors. As Ruiz Larraguivel (2007) clearly stated when talked about the main strategy this type of school has, as follows,

This policy was the implementation of strategies of strong ties with productive and services sectors. The school-company linkage would be the central axis over which activities and academic programs will hinge. This would establish different organization methods to allow a direct participation of groups of businesses to impact academic and administration decision-making. (p. 114)

To do so, this new system of TU was decentralized with an evenly split financial support between the Secretary of Education and the local states. This way, each school had more autonomy to decide for they curriculum and their interaction with diverse groups of local industries and services.

Throughout six quarters, students have to complete 3000 hours of schooling with $70 \%$ of practical training and $30 \%$ of theory (a 70/30 curriculum model). Each program has $20 \%$ of classes that are aligned with regional needs while the $80 \%$ remaining are the same as the rest of technological universities helping academic mobility within the

2 The Secretary of Education is the equivalent to Ministry of Education. 
organization. The system of TU was inspired in the actual French model of Instituits Universitaires de Technologie (IUT). Since 1966 these institutes have been offering university degrees in two years of training. The main goal is to provide a professionaloriented diploma with an evenly split time of 50-50 percent for theory and practice. In the Mexican case, this academic rank is given only through this new type of higher education institution created exclusively for that purpose. Unlike the Community College and the French IUT models, this institution represents a closed structure that has almost no mobility within the Mexican tertiary education system (Silva Laya, 2006). However, as it can be seen in graph 1, enrollment has soared from 426 in 1991, when it opened with 3 universities, to a bit more than 100000 in 2010-11 distributed in 73 institutions. In about ten years, from 1991 to 2001 the model has been able to multiple one hundred times its initial enrollment (from 426 to 42609 students). However this is an important growth, it only represents a $3.8 \%$ of the total enrollment in the Mexican higher education system. The student/institution ratio is of 1376 and according to Flores Crespo (2009) almost half of the universities are below 1000 students, a rather low number of students for the structural investment.

Graph 1. Enrollment growth of Technological universities 1991-2010

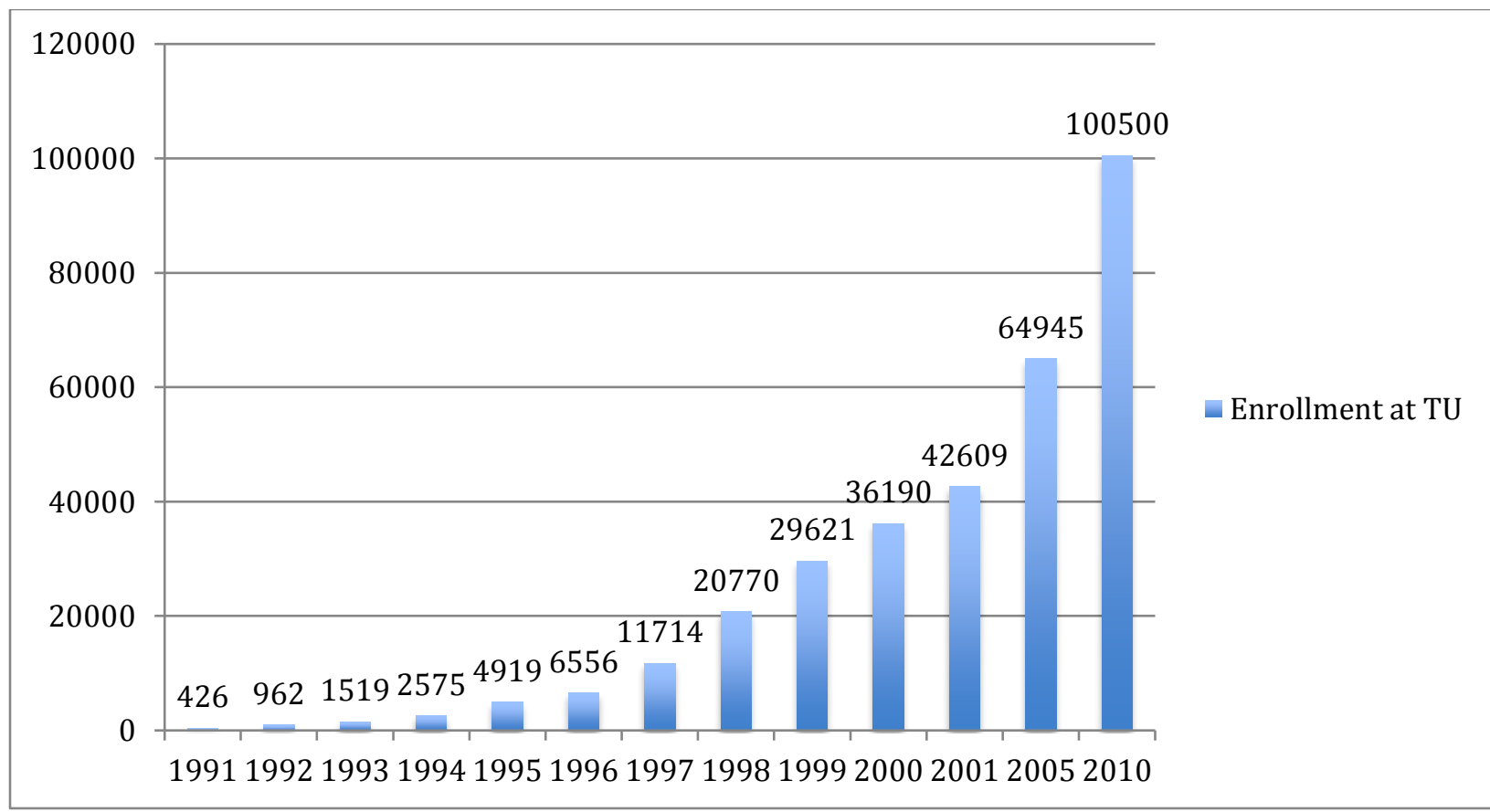

From SEP's databases and Secretary of Technological Universities (http://cgut.utleon.edu.mx/images/stories/CGUT/estadistica/Rendicióncuentas.HTM)

Overall, and according to Villa Lever and Flores Crespo (2002, pp. 8-9), the Mexican government had three basic reasons for creating this two-years degree. The first one, it's related to the general assumption that more trained people will lead to better human resources and therefore more development. Workers with higher levels of training are better positioned to compete for opportunities and, most of all, to adjust to labor market 
changes. Following the general assumption of Human Capital Theory, education is a key factor for the development of economies, especially technological training. The second reason responds to the intrinsic need of diversifying and enriching the actual system of education, making it more flexible to poor or disadvantaged students who cannot access the tradition bachelor. This is also very much linked with the low percentage of Mexican young people attending tertiary education, that back in the 90 's was less that $20 \%$ and today is about $27 \%$, but still below the OCDE average. Also, following the same argument, Ruiz Larraguivel (2009) pointed out that the main goal was to provide a degree for low performing students that would help them to get a job. Finally, the government bet that these technological degrees would be as a booster for the economy and an opportunity for young people from, especially, lower social classes. These short degrees would facilitate, on one hand, real jobs to the growing demand of middle rank technicians in the Mexican industries and service sectors, and, on the other, encourage students to continuing studies bridging the gap toward a full university bachelor. All these basic purposes are very much interwoven with the international context that surrounded Mexico at the beginning of 90s, as it was mentioned above.

\section{Research design}

The information for this research is drawn from two sets of sources. The first one is obtained through existing databases already collected by different researchers as well as current policies dealing with this type of university. Secondly, and most important, sets of qualitative interviews were done with human resources directors who hire graduates from these universities. Due to the lack of information regarding how managers perceive graduates from TU, I conducted six meetings with human resources directors in several main companies and factories of Monterrey area, northern Mexico. These directors are a central part in employing personnel and can share information about workers with diplomas from these universities. Moreover, students need to do numerous internships and interact with these local companies. I wanted to see whether employers perceived differences in the quality of training among workers associated with the type of institution granting their degrees (two-years versus four-years degrees) and if that was an issue to hire them.

For the exploratory and qualitative part of this study, I selected companies and industries that provided jobs in the areas of food-agriculture, automotive, chemical-plastic, and health. These areas of production and services are the most important in the region. The payroll of these firms ranged roughly as follows: one with 100, two with 250, one with 2500, and the last with 4600 employees. In addition, I interviewed a CEO belonging to a main recruiting business in Monterrey. He provides personnel for the principal companies in the region.

It is important to underscore that Monterrey and metropolitan area offer a high concentration of national and international industries, companies, and several types of businesses. This is the biggest city and most industrial hub for the whole Northern part of the country. It has been one of the main developers of the Mexican Maquiladora, which is still much alive in the area, even though the drug cartels have impacted negatively since 
2009. At the same time, the region has a very wide spectrum of private and government universities, including technological universities, a perfect match for this study.

The human resources managers were asked to the following two general questions: 1) Do employers see a degree from a TU as of inferior quality and in disadvantage to find a job on their field of training? 2) What aspects does a recruiter judge as most important for hiring a technician like the ones TU produce? Further questions were made as the interviews evolved. New questions were added, depending on the flow of the conversation, with some comments from both the interviewer and interviewees. The dialogues were digitally recorded and transcribed. Some field notes were made during and after each interview. In addition, some other sources of data, such as via the Internet and hard copies of records, were examined to verify information shared during the interviews and to expand the validity of the findings.

This methodology allows me to have real cases and explore employers' perceptions regarding these new degrees and human resources coming out technological universities. Although technological universities have been evolving and growing fast, over the last twenty years, there is little research on what employers value or question about graduates from TU. Qualitative methodology is a good fit for studies where the lack of information is significant (Creswell, 2005). In addition, the information collected here is critical to assess within a real scenario some of the Human Capital Theory assumptions, as one of the goals for this study.

\section{Interviews - Emerging concepts}

After having the different interviews, the following themes emerged as clear issues for hiring technician with university degrees. Human directors discussed some of the advantages and challenges these shorter universities programs have to face in order to have a greater impact in industries and employees.

\section{Job's profile and attitude}

Several directors mentioned that what is really relevant for hiring a new employee is much related to the characteristics of a specific task. In other words, does this or that potential applicant match what we need? The following quotations clarify this central concept,

The first thing we look here is that the person would match our needs. We don't do any particular upfront discrimination of any university or degree. We look for experience, technical knowledge, and what the potential employee has done in the field. We also do some standardized psychometric tests to assess IQ, learning style, personality, and general psychological traits as complementary profiles.

\section{Another said:}

To me everything depends on the recruiter's background. For instance, I come from a working class. I understand people's needs and I'm careful with poor, but hard 
working people. Everything, to me, depends on the need I have here. But I know that some of the poor applicants went to a TU because they had to work and study during the night and that gives them some resilience that other more sophisticated applicants don't have.

This one added the value of attitude:

As recruiter, I want to see that the person would align with our corporative values. We like people with enthusiasm and willingness to do things in diverse situations. We are looking for people with high managerial skills. The degree gives you a $20 \mathrm{o}$ $30 \%$ of what is needed, we provide an intensive training here. Experience will give you the rest.

Another said something similar:

We look for people who have invested in their education, even though they didn't have the best opportunities, but he worked his way up through an alternative education to succeed. That has a huge value for us. That person has a hunger for success.

These recruiters are saying that even though the title is important, what really matters is a combination of training, experience, attitude, and most of all, matching what they need. These general characteristics give to graduates from a TU a chance to compete even though they may compete against applicants with full bachelors and more prestigious institutions. These perceptions and procedures seem to be enough for initial jobs or somehow less sophisticated within a specific area of activity. However, if there is a more selective position with complex and key roles, the stratification may occur, as the following opinions evidence:

We give an opportunity to all for some areas. But for specific and sophisticated jobs, like marketing or some top positions, we tend to have a list of universities where we go for hunting. Degrees from a TU are not enough.

This recruiter added the same idea:

Yes, I have some clients who want to have applicants from a selected pool of universities. In some companies you cannot get a job if you don't come from this or that school. Which is a very stupid thing to me, because success does not depend only on IQ or training. A title is not synonymous of success. It is the person, his or her skills.

Even though two-years degrees are a good option for some recruiters giving opportunities to graduates from a given TU, some companies and businesses tend to stratify employers based on tasks and type of school. Moreover, there are networks already installed within universities for facilitating students' jobs. Recruiters, for instance, from those universities, later on, tend to hire workers from the same alma mater, as one 
recruiter said, "we prefer students from schools we attended and from programs we know to provide for our needs."

\section{The advantage of technological universities' degrees}

Several recruiters mentioned that workers coming from a TU have some benefits when compared with degrees from more prestigious institutions. For instance, this one emphases the willingness to work in whatever is needed:

Each university has it own identity that distinguishes them. Graduates from a TU are people for the battle. I'm not going to bring here a guy from a prestigious school who has a psychological expectation that is not according to our reality. Even if I can pay him, I prefer an employee who is trained to work hard. I must know each university's profile and how these schools train students. Technological universities are great for hard work.

In addition, this one said:

Some companies don't want people from some prestigious universities because those students come with unrealistic expectation for salary and work. They want to be bosses right away and that is ok as long you have the experience. We have a process of experience that you need to pass through to be boss.

Another added:

Potential employees from prestigious universities come with skills that are not always aligned with our needs. The TU trains students in a 70\% practice and 30\% theory, they start working from the beginning and that helps them to get acquainted with what is going on in industries like ours.

Evidently, these recruiters are thinking of middle managers or workmen who can handle not highly sophisticated jobs. They see that TU's people are prompted to tackle most of the demands at a regular working floor. Moreover and according to the following quotation, two-years degrees are also much better than an average worker, which is a very important appreciation for these new degrees,

The technicians know how to find causes - effect relations to solve problems. He brings in a methodology to work looking for details. I perceive that they tend to like their jobs and they aren't there only for a paycheck. They are motivated to do well and to learn improving their performance.

The same human resources director also said that although these technicians are not very well paid, they bring to the factory leadership, managerial and conceptual skills that are very important for an industry, 
In addition to technical skills, these technicians bring in administrational capabilities that enhance they performance making them more attractive to employers. Even though they aren't at an engineer level, they are better than a regular worker. An employee has $20 \%$ of administrational skills and $80 \%$ of technical knowledge. The two-years technician has 50-50, which is a plus for them.

The following employer also saw a very positive enhancement of his workers while they are attending a close by Technological University,

Here in our company we have a group of seven employees that are studying in the Technological University of Santa Catarina their two-years degree. They are putting a lot of efforts and you see how they are having a different mindset. That's the influence of higher education because you stop being a worker by hours to become one who thinks and contributes to the company. These employees are much better now bringing new ideas and proposals.

These employers' opinions are in consonance with other studies that found positive correlations between two-years degrees and improving job's performance and satisfaction (Damián Simón, Arellano, \& Lluvia, 2009). Technical degrees seemed to be helping general routine within a working floor performing better than a regular worker. In addition, these employees aren't as expensive as the ones with a full bachelor. As a recruiter said, "I see that here two-years degrees are similar to what is happening in the US, they are very useful for industries and give a great opportunity to poor students." This process of hiring technical employees seems to be picking up in Mexico where a growing number of employers see the advantages of this type of training. Even though these technicians are introducing themselves as an alternative with many positive advantages over an untrained worker, two-years degrees are new to most of employers, even after 20 years of the making, according to Damián Simón et al. (2009). Also, the difference between this degree and a technical high school diploma is not quite clear.

\section{Challenges of TU degrees}

Though a two-years degree at technological universities is designed to have a $70 \%$ of its time dedicated to practice, several recruiters saw that there are areas of challenge to adjust better to industries' needs. Some of the missing aspects in training technicians are described in the following quotations,

At these technological universities, students get a technical knowledge that is far from industrial processes. Maybe they use outdated machinery for their training, I don't know. It is difficult to catch up with real businesses. But the basic things are there and these students know the essential processes even better than an engineer. But these technicians aren't focused to specifics needs employers have. If universities dialogue better with industries, we, as recruiters, could do a matching to help both parties. The idea is to know each other so the graduates would have fewer problems to find a job. 
This other employer shifted to his concerns about the way professors at technological institutions are hired and teaching skills,

Professors must also have some experience in the real world of companies, businesses, and industries. The idea of technological universities here in Mexico means that students go through $30 \%$ of theory and $70 \%$ of practice. These schools are an option for some students who want to work in the automotive industry, for instance. But professors must be practical. They question is: how do we hire teachers? Do they have real experience in any industrial sector? Sometimes I see that these universities have problems to live up to their own expectations.

Also,

Another important challenge is the certification for teachers, since several of them don't know how to teach. I would push harder and get accreditations to certify my teaching and quality.

The relationship between these universities and real industries still poses, after twenty years, some problems. In theory, this model of 30/70 is an innovative one in Mexican higher education but according to interviewees there is a risk of detachment from the challenges industry is facing. Professors and facilities are not quite aligned with the demand students confront when they leave their schools.

In addition, and according to a human resources director who works in a TU, students also present some challenges due to differences in ages and other characteristics, as follows,

In the TU where I work, there is an important disparity between students who are attending classes in the morning and those who do it in the evening. The morning group is well behind and is not entirely interested in having hand-on experiences. They seem to be there because someone sent them to do something. We need to approach these students differently; otherwise, we'll have graduates out touch.

This recruiter is pointing out a problem that is well beyond technological schools and starts in lower and previous levels of education. One of the problems universities face is that educate people in a brief period of time. Young students may think they have the skills for working when in reality they are ill prepared for the task. This is a problem of quality that affects graduates and probably the overall system (Silva Laya, 2006).

Two-years graduates, unions, and jobs

One of the emerging issues graduates must face in Mexico has to do with the power and control unions have over the pool of available jobs. This is especially true in the public sector. Government funded services and companies are a huge source of employment. The following set of quotations shows that finding jobs is not always correlated to training of any kind. There are perverse systems that go against what an advance society would like to see to promote social mobility, as this recruiter asserts, 
Mexico is a monopolist country. Many firms are unionized. Therefore, workers pass jobs on to their children or even relatives. People don't really care about where to get a diploma (TU, private, public, etc.) since they already have a secured position through unionized mechanisms that inherit jobs. Some year ago, people used to get a position without any diploma, but today unions require more to align themselves with modern times. But it is highly irrelevant where you get you degree.

Another added,

If I had a position at the Social Security Sector, I can have, for instance, five applications, that are jobs for sure, to be distributed among my family or relative members. If I'm looking for a job, I must have a relative who may hand me an application. Obviously, the inside worker needs to provide his or her personal information for the application to be processed.

These previous recruiters are expressing same of the common practices among unionized companies. There is a strong control many unions are exerting over employment opportunities. Some employments are sold or inherited as if they were personal possessions. Even private businesses seem to be impacted by these practices, as the following recruiter worded it,

The private companies may screen people according their level of training. Some of them come from overseas to this region of the country with their personnel already selected. Based on personal qualifications, some applicant can find a position among them. But for initial applicants, in my opinion, and among Mexican companies, you must have an inside contact to have good chances of getting a job.

These cultural factors influence negatively the way enrollment of new personnel is done. The process among public services seems to follow alternative paths that are far from being rational. Applicants may know this and use all complementary networks to get hired. One important reason that comes from interviews and may help to explain some of these behaviors has to do with the limited slots available for applicants. Mexico has a growing group of young people and the economy does not seem to provide enough jobs for the increasing demand (Flores Crespo, 2009). Unions and social networks offer alternatives to have some predictability among selected groups. This social mechanism appears to be created as a way to ensure stability when looking for jobs.

\section{Discussions}

One hand, and based on the general goals for this paper, this section turns to some of the theoretical implications that can be inferred from interviews and other studies. It analyzes some of the limitations that Human Capital Theory faces. And on the other hand, it presents some of the challenges technological universities must address to overcome shortcomings in order to fully develop the model's potential. 


\section{Theoretical implications}

Human Capital Theory (HCT) (Schultz, 1961, 1971 and later Becker, 1975) is probably one of the most quoted theories for backing up policies among policymakers. It posits that personal income vary according to the level of investment in education. People would invest in education as a way of improving their income and opportunities. It is generally assumed that a country advancing its human resources will have a better-trained labor force that will, accordingly, translate into an economic progress. The productivity of any given worker increases proportionally with the skills that a person acquires during his or her lifespan. With this conceptual background, innumerous policies were promoted for higher education in Mexico and elsewhere as well (Damián Simón, 2011). However this is true, the assumptions of this theory are not quite tailored to what is happening with graduates from technological universities in Mexico.

If two-years diploma is understood as a way out for poor young people who want to improve their lives and have better opportunities, then the degree in itself isn't enough for accomplish this goal. Although there are some evidences in developing countries (Martínez Torres, 2005; Navarro Leal, 1998; Olaniyan \& Okemakinde, 2008; Ramsey, Carnoy, \& Woodburne, 2000; Ruiz, 1997) to support that improving human resources is positively correlated to economic growth, the Human Capital Theory fails to take into account several dimensions, as follows:

a. First of all, productivity and better income do not depend in many cases on training, whether it is on the job or formally learned. Mexican Unions are powerful organizations acting as underground forces that impact employment based on non academic or skills competencies, as was expressed in the interviews. In other words, getting hired does not follows a clear correlation with graduates as it might be expected. According to a study that Flores Crespo (2005) conducted in the Technological University Tula-Tepeji, about $41 \%$ of their students found a job using informal contacts (friends, relatives, teachers, among others). These findings match what was expressed in the interviews. Firms and recruiters take into account several other factors that are not necessarily linked with a rational process of higher levels of skills.

b. Second, jobs are socially distributed within a host of conditions that interact with opportunities. The stratification that gender, races, social status, among others, produces is a clear example in Mexico where man dominates most of technological jobs. Damián Simón et al., (2009) found out that these two-years degrees are not fully understood. Only a small fraction of them get the same opportunities to grow within their jobs. As a consequence of this type of segmentation, pay is also much lower while similar tasks are performed. These barriers are hard to break even though employees continue to specialize.

c. Third, employers, who use different scale of trainings for their businesses, appreciate degrees in a very wide spectrum. Depending on the task, they may apply criteria of stratification that put University-trained Higher Technician as of inferior condition to compete when compared with other university degrees. As Flores Crespo (2005), quoting McNabb (1987), mentioned, each employment sector has its own mechanisms of rewards (p. 40). Selection is not quite a lineal procedure for all industries and services. 
d. Forth, jobs seem to speed up training than the way around. Mexican population grows faster than the few employments available creating a natural competition that demands more and more "credentials" to be hired. This situation has generated a boom for higher education feeding the cycle. Muñoz Izquierdo (1990) talked about the "theory of education as a positional good" describing how in an increasing market of more educated people it is important to have more education to compete. This is happening for the sake of a reduced number of available positions. It is possible, then, to have an overeducated population with high levels of unemployment, an important factual objection to what HCT proposes. Moreover, in an environment of abundant jobs, stratified formal training may not play the same key factor for hiring workers.

e. Finally, and as it was mentioned, unemployment of highly skilled people is a direct contradiction to the core of this theoretical approach. Mexico faces an important percentage of engineers and also University-trained Higher Technician without jobs. This is a severe challenge to this theoretical framework. As Livingstone (1997) pointed out, alternative reforms are needed,

Ultimately, we need to recognize that it is not improved learning practices but economic reforms that hold the solution to the education-jobs gap. We can and should reorganize our workplaces to apply more of the labor force's currently wasted knowledge and work skills. (p. 12)

These changes of structural processes may be painful, but necessary to match employment and learning. Education in itself will not solve the social iniquities and problems of wealth distribution. This is a task that may start in the school, but goes well beyond its walls. As Brown, Lauder, \& Ashton (2011) put it, "We therefore need to focus on how occupational opportunities are being transformed in the global division of labor rather than simply focus on the supply of marketable skills" (p.124). There is a certain level of disconnection between society, say universities, and markets.

In other words, the main thesis of the theoretical discussion is that more education, including alternative models of technological universities, will not provide by itself an economic growth and therefore a better lifestyle for the poor generations of this country (Garay, 2003). Yes, education is necessary, but it must be complemented with a set of social and economic reforms in order to have the impact that it can bring out.

\section{Implications for the model}

As it was mentioned before, this new model of two-years degree was an altogether innovation for the Mexican academia. The general goal of leveling, through education, poor and disadvantaged young people was an important step toward improving their opportunities and progress. Although the system of Technical Universities has reaped positive results, existing reforms need to go further considering the following challenges: 
a. The relevance of offered training. According to some of the human resources directors, many of the programs have a lack of connection with what is going on in real working places. To solve some of the natural mismatch with current technology, schools need to work closer with businesses and service sectors. According to a study Silva Laya (2008) conducted, students perceived their training too much oriented to theory. This is an important finding since the model proposes $70 \%$ of practical teaching. Situations as these are probably a consequence of a strong academic culture of theoretical lectures that is present not only in Mexico, but in many Latin America countries. Creating seminars, workshops, and more specialized internships would develop stronger linkage between these universities and companies. It is important to underscore that these activities are part of the general model, but somehow they seem to be disconnected or not working as they originally were thought. Training students to work is very relevant to these two-years programs; therefore, technological universities need to bridge in creative ways to accomplish this important goal reengineering linkages to reach an effecting impact on students and later on industries and businesses.

b. The previous point leads to the issue of teachers at technological universities. One of the interviewees expressed that some of the professors didn't have the right connection with industries, situation that may drag down the whole model's idea of being integrated with jobs. Silva Laya (2009) found similar concerns in her studies. In addition, she point out that many of the professor don't seem to have the teaching skills to train students. Finding professors linked to industrial sectors and capable of delivering good classes is a rather complicated goal. Administrators will have to work around and coach their teachers on the job.

c. Technological universities have not reached their potential. As the Mexican higher education system sets for recruiting more poor students, this model of institution must expand faster. Although the Secretary of Education is promoting scholarships through programs for poor as PRONABE 3 , after 20 years these universities have reach a 3.8\% share of the total university enrollment. A second wave of students (Ruiz Larraguivel, 2009) that dreams with a majority of young people in tertiary schools will demand a more aggressive agenda. The figure of "University-trained Higher Technician" appears unclear to many organizations and needs better advertising among, first of all, young people without neglecting employers.

d. Mobility within the Mexican higher education system is still a challenge. At the beginning technological universities offered a two-years degree with no second cycle for a full bachelor. Today, many of these institutions are offering full degrees taking into account the first two-years. This is a progress and a good option for most of students who may want to become, for instance, an engineer. But this option in not available at all universities because of their low enrollment and location. This problem intensifies when a student wants to transfer to another university, since most of the Mexican universities will not take credits done in one of these institutions. The same model of 70/30 percentages of practice and theory presents a challenge for arranging equivalences. This problem in matching credits and

${ }^{3}$ PRONABE is a national system of scholarships for poor young people who want to access higher education. For more information, see http://www.pronabes.sep.gob.mx/ 
programs goes against the development of two-years institutions. It promotes a kind of auto segregation that segments students and universities. It is highly necessary to achieve some agreement to easy mobility, like in the American Community College (Latiner Raby, 2009). Perhaps, modifying the 70/30 model toward, say, 50/50 like the French Institutes, would help students to transfer credits.

e. Competing systems of technological education. It appears that many technological universities are going after a full bachelor, a fact that seems to be a step forward to expanding opportunities to students. But this move is creating a natural competition with existing National Polytechnic Institutes and traditional universities that offer similar degrees. This overlapping scenario is even more difficult to understand when confronted with the recent creation of another system of tertiary institution called Polytechnic Universities ${ }^{4}$ in 2000. These schools were set to teach through the development of competencies as a revolutionary curricular model. They offer full four years degrees and graduate programs. It seems that the Secretary of Education creates new parallel systems of technical education, since it cannot reform the existing ones, situation that may reinforce stratification of institutions and students. As Flores Crespo (2009) pointed out, "What is the advantage of doing a bachelor degree in a technological university versus a Polytechnic or a National Institute of Technology?" (p. 49). This is building a competition within the Mexican higher education system that has no clear rules and means a lot of money spent unwisely.

\section{Conclusion}

As the data from interviews show, employers seemed to consider a host of factors to hire a graduated with a technical degree. First of all, it is central to have a matching between a potential applicant and what a company needs. The profile of a position was very important for all the recruiters. Secondly, it is also relevant, for an applicant with a two-years degree, to have a learning attitude to adjust to what industries demand. Human resource directors look for people who would be able to work with their existing teams. They want to see a positive potential in any given employee and if that person is "trainable" to their company's culture and comes with good basic skills already tune-up for their working places. Third, most of the recruiters saw people with a two-years degree as hard workers, far more competent than an untrained one. Therefore, these three broad aspects offer graduates from technological universities a realistic and positive set of possibilities to be hired. However, when a more selective position is available, stratification tents to occur. Employers manifested some degree of elitism depending on the type of task. In addition, existing networks that recruiters already have may disturb a lineal and rational application process. These links with personal preferred schools may come against small and new institutions such as the one studied in this paper. Interviews also revealed areas of deep

\footnotetext{
${ }^{4}$ Polytechnic Universities were created in 2000 with an alternative curricular model based on teaching through competencies to avoid the traditional model of training. For more information, see http://politecnicas.sep.gob.mx/ModeloEducativo.html
} 
challenges for graduates when searching for jobs. The highly unionized companies and a strong culture of inherited jobs may go against a coherent process that would facilitate ways for the best talents to be employed.

Interviews gave some important evidences to question some of the central postulates of the Human Capital Theory. The fundamental assumption that more training would lead to more job opportunities is not always a happening in Mexico. This paper shows some of the pitfalls this theoretical framework has. Getting hired is actually a multi factorial interaction. At the same time, and as a consequence of this complexity, promoting education would not necessary lead to improving people's economy. Structural problems must be addressed to complement good education that would translate into personal and regional improvements.

In addition, the model of technological universities has significant challenges that ought to be considered for a successful development over the years. Policy makers face issues in flexibility and mobility within the Mexican higher education system, teaching quality, relevant training for students with qualified professors, and, among others, overlapping institutional isomorphism (Di Maggio \& Powell, 1983) with high costs of duplication, that the same government is promoting through multiples systems of higher education. However these challenges are nearby, so far, this new model of two-years degrees has accomplished much for poor and needy students. It has been a door to leveling people. It is also, with the right adjustments, a good example for many other Latin America countries that confront similar situations. Improving it will lead to a better Mexican society. 


\section{References}

Becker, G. (1975). Human capital: A theoretical and empirical analysis, with special reference to education. ( $2^{\text {nd }}$ ed.). New York: Columbia University Press.

Brown, P., Lauder, H., and Ashton, D. (2011). The global auction: The broken promises of education, jobs and income. Oxford: Oxford University Press.

Creswell, J. (2003). Research design: Qualitative, quantitative, and mixed methods approaches (2nd ed.). Thousand Oaks, CA: Sage.

Damián Simón, J. (2011). El Técnico Superior Universitario en administración: origen, trayectoria estudiantil y desarrollo profesional. Málaga: Universidad de Málaga.

Damián Simón, J., Arellano, M., and Lluvia, J. (2009). Calidad profesional del técnico superior universitario en administración. Una visión de graduados y de empleadores. Revista Electrónica Actualidades Investigativas en Educación, 9(2), 130.

Didou, S. (2002). Las políticas de educación superior en los institutos tecnológicos federales: una reforma inconclusa. Revista Mexicana de Investigación Educativa, $7(14), 51-73$.

Di Maggio, P., and Powell, W. (1983). The iron cage revisited: Institutional isomorphism and collective rationality in organizational fields. American Sociological Review, 48, 147-160.

Flores Crespo, P. (2005) Educación superior y desarrollo humano. El caso de tres universidades tecnológicas. México: ANUIES

Flores Crespo, P. (2009). Trayectoria del modelo de universidades tecnológicas en México (1991-2009). Dirección General de Evaluación Institucional de la Universidad Nacional Autónoma, México. Cuaderno de Trabajo 3.

Garay, A. (2003). El perfil de los estudiantes de nuevo ingreso de las universidades tecnológicas en México. El Cotidiano, 19(122), 75-85.

Ibarra Colado, E. (2002). La "nueva Universidad" en México: Transformaciones recientes y perspectivas. Revista Mexicana de Investigación Educativa, 7(14), 75-105.

Latiner Raby, R. (2009). Defining the Community College model. In R. Latiner Raby and Valeau, E. (Eds.), Community College Models. Globalization and higher education reform (pp. 3-19). UK: Springer.

Livingstone, D. W. (1997). The limits of Human Capital Theory: Expanding knowledge, informal learning, and underemployment. Policy Options, July/August, 9-13.

Martínez Torres, A. (2005). Generación 2000: Inserción laboral. Primera aproximación al seguimiento de egresados de la UAMCEH de la UAT. Revista Internacional de Ciencias Sociales y Humanidades, SOCIOTAM, XV(1), 117-145.

Muñoz Izquierdo, C. (1990). Relaciones entre la educación y el sistema productivo. Revista de la Educación Superior, 19(76), 63-101.

Navarro Leal, M. A. (1998). Consideraciones teóricas para el estudio de egresados. En esquema básico para estudios de egresados en educación superior. México: ANUIES

Olaniyan, D. A, and Okemakinde, T. (2008). Human Capital Theory: Implications for educational development. European Journal of Scientific Research, 24(2), 157-162.

Ornelas, C. (1995). El sistema educativo mexicano: la transición de fin de siglo. México: Fondo de Cultura Económica. 
Ramsey, G., Carnoy, M., and Woodburne, G. (2000). Aprendiendo a trabajar. Una evaluación del Colegio Nacional de Educación Profesional Técnica y del sistema de universidades tecnológicas de México (Resumen ejecutivo). Revista Mexicana de Investigación Educativa, 5(10), 327-354.

Ruiz, C. (1997). El reto de la educación superior en la sociedad del conocimiento. México: ANUIES.

Ruiz Larraguivel, E. (2007). Sustentos de una política de reforma en la educación superior: El caso de las universidades tecnológicas. Revista de la Educación Superior, XXXVI (4)144, 111-118.

Ruiz Larraguivel, E. (2009). Los técnicos superiores universitarios. Diferenciación educativa, estratificación social y segmentación del trabajo. Revista Mexicana de Sociología, 71(3), 557-584.

Schultz, T. W. (1961). Education and economic growth. In N. B. Henry, (Ed.), Social forces influencing American education. Chicago: University of Chicago Press.

Schultz, T. W. (1971). Investment in human capital : the role of education and of research. New York: The Free Press.

Silva Laya, M. (2006). La calidad educativa de las universidades tecnológicas: su relevancia, su proceso de formación y sus resultados. México: ANUIES.

Silva Laya, M. (2008). ¿Contribuye la universidad tecnológica a formar las competencias necesarias para el desempeño profesional? Un estudio de caso. Revista Mexicana de Investigación Educativa, 13(38), 773-800.

Silva Laya, M. (2009). Technological universities: A relevant educational model for Mexico? In R. Latiner Raby and Valeau, E. (Eds.), Community College Models. Globalization and higher education reform (pp. 219-233). UK: Springer.

Villa Lever, L., and Flores Crespo, P. (2002). Las universidades tecnológicas en el espejo de los institutos universitarios de tecnología franceses. Revista Mexicana de Investigación Educativa, 7(14), 17-49. 